Article

\title{
Effect of Carbon to Nitrogen Ratio on Water Quality and Community Structure Evolution in Suspended Growth Bioreactors through Biofloc Technology
}

\author{
Jingwei Gou ${ }^{1}$, Chol Ung Hong ${ }^{1,4}$, Min Deng ${ }^{1}$, Jieyu Chen ${ }^{1}$, Jie Hou ${ }^{1,2,3}$, Dapeng $\mathrm{Li}^{1,2,3}$ and \\ Xugang $\mathrm{He}^{1,2,3, *}$ \\ College of Fisheries, Huazhong Agricultural University, Wuhan 430079, China \\ Hubei Provincial Engineering Laboratory for Pond Aquaculture, Wuhan 430079, China \\ Freshwater Aquaculture Collaborative Innovation Center of Hubei Province, Wuhan 430079, China \\ Aquaculture Faculty, Wonsan University of Fisheries, Wonsan 9990153, Korea \\ * Correspondence: xgh@mail.hzau.edu.cn; Tel.: +86-158-2711-8986
}

Received: 31 May 2019; Accepted: 5 August 2019; Published: 8 August 2019

\begin{abstract}
Application of biofloc technology could effectively treat wastewater. However, the effect of influent carbon to nitrogen ratio ( $\mathrm{C} / \mathrm{N}$ ratio) on water quality and microbial community structure evolution in suspended growth bioreactors (SGBRs) through biofloc technology is still unclear. Here, we show that the total ammonia nitrogen (TAN) and nitrite nitrogen in the effluent of the $\mathrm{C} / \mathrm{N} 10$ treatment was significantly higher than that in the $\mathrm{C} / \mathrm{N} 15, \mathrm{C} / \mathrm{N} 20$ and $\mathrm{C} / \mathrm{N} 25$ treatments $(p<0.05)$. Higher TAN removal efficiency was obtained in treatments of C/N 15, C/N 20 and C/N 25, and there was no accumulation of nitrite nitrogen and nitrate nitrogen. Increasing the $\mathrm{C} / \mathrm{N}$ ratio strengthened the elimination ability of total phosphorus and chemical oxygen demand (COD). The concentrations of TAN and COD first dropped to the lowest level and then increased slightly within one cycle in all treatments. The accumulation of biomass in the reactors increased with the increasing $\mathrm{C} / \mathrm{N}$ ratio, indicating that a higher $\mathrm{C} / \mathrm{N}$ ratio was conducive to microbial proliferation. The $16 \mathrm{~S}$ rRNA sequencing revealed that the microbial community diversity in SGBRs was significantly higher than that in the natural wastewater (P0). The predominant phylum were Proteobacteria, Bacteroidetes and Verrucomicrobia, but Saccharibacteria occupied a dominant position in the late period of the experiment. Pathogens, such as Aeromonas, Acidovorax, Flavobacterium, and Malikia were significantly decreased after high $\mathrm{C} / \mathrm{N}$ ratio simulative wastewater treating natural wastewater in the reactors. In summary, the water quality and biomass concentrations in SGBRs can be improved under the conditions of influent $\mathrm{C} / \mathrm{N}$ ratio, equal to or greater than 15 .
\end{abstract}

Keywords: $\mathrm{C} / \mathrm{N}$ ratio; biofloc technology; biomass concentrations; $16 \mathrm{~S}$ rRNA sequencing; microbial community

\section{Introduction}

Biofloc technology (BFT) has received increasing attention in enhanced water quality and improved products by heterotrophic bacterial growth to assimilate unemployed nitrogen species (most of ammonium) in aquaculture systems and bioreactor systems [1-3]. The nitrogen uptake by bacterial growth was promoted through adding an external carbon source to the pond water or elevating carbon content of the feed [1,4]. Avnimelech [5] reported that bacteria require about 20 units of carbon per unit of nitrogen assimilated, while the $\mathrm{C} / \mathrm{N}$ ratio of most feeds used in pond aquaculture is around 10. Therefore, it is necessary to supplement the carbon source to increase the $\mathrm{C} / \mathrm{N}$ ratio for bioflocs production in aquaculture systems, especially for treating pond wastewater with high nitrogen 
concentration [6,7]. Increasing the $\mathrm{C} / \mathrm{N}$ ratio to promote bioflocs in pond wastewater systems controls water quality through the removal of toxic nitrogen species, such as ammonia [7]. Since bioflocs mainly relies on heterotrophic microbes to perform functions, the faster growth rate and higher microbial biomass yield per unit substrate of heterotrophs than that of nitrifying bacteria means that the fixation of ammonium by heterotrophic bacteria occurs much more fleetly [8]. Therefore, the carbon to nitrogen ratio determines the growth and reproduction of heterotrophic microorganisms in bioflocs [9]. The bacterial protein produced by ammonia nitrogen assimilation showed an adequate protein, lipid, carbohydrate and ash content as a quality aquaculture feed $[10,11]$. The biomass concentrations reflected the bioaccumulation of bioflocs. Therefore, the different $\mathrm{C} / \mathrm{N}$ ratios of wastewater would definitely lead to different measurements of biomass concentrations, despite the scarcity of literature on this topic.

In BFT, utilization of a separate biofloc reactor could prevent the decrease of dissolved oxygen in water due to the microbial metabolism for the decomposition of organic matter [12,13]. Dissolved oxygen that is too low is fatal to fish. Previous reports indicated that bioflocs produced suspended growth bioreactors (SGBRs) that can be used as feed [14]. Additionally, the total ammonia nitrogen (TAN) concentration can be controlled and the aquaculture solid waste can be recycled and reused through SGBRs $[3,14]$. Asaduzzaman [15] showed that $10 \mathrm{mg} \cdot \mathrm{L}^{-1}$ ammonia nitrogen can be completely transformed within five $h$, while the trend of ammonia nitrogen in one cultural cycle in SGBRs is still unknown, especially under different $\mathrm{C} / \mathrm{N}$ ratios.

Biofloc consists of microorganisms, particles, organic polymers, colloids and dead cells [16]. The microorganisms are the main component and play a key role in bioflocs. Heterotrophic and autotrophic bacteria are involved not only in the biomass concentrations but also in nitrification and denitrification in aquaculture systems [17-19]. The C/N operational parameter of biofloc systems directly influences the composition of the microbial community in the bioflocs [20]. Previous reports indicated that bioflocs protected against bacterial diseases [21]. Comprehending the community structure of bacteria in bioflocs can help in understanding the maximization performance of SGBRs, and different $\mathrm{C} / \mathrm{N}$ ratios would affect the composition of the microbial community.

In this study, by controlling the $\mathrm{C} / \mathrm{N}$ ratio of simulative wastewater we observed the effect of TAN removal and measurements of biomass in SGBRs. We used tracking tests to understand the trend in changes of key indicators in SGBRs in one cycle. Additionally, by monitoring the evolution of microbial communities, we sought to understand the changes in functional microbes of bioflocs and provide further research data to improve the performance of bioflocs.

\section{Materials and Methods}

\subsection{Setup of Reactor and Operation}

The experiment was carried out in 12 10-L (total volume) lab-scale suspended-growth bioreactors (SGBRs) which were operated in an intelligent artificial climate incubator (Ruihua Instrument \& Equipment Co., Ltd., Wuhan, China). Each reactor had a diameter of $20 \mathrm{~cm}$ and a liquid filled height of $20 \mathrm{~cm}$ (=6 L working volume). The temperature was stable at $26 \pm 1{ }^{\circ} \mathrm{C}$ in the climate incubator which was thought to be favorable for the growth of bioflocs. In addition, each reactor was supplied with air by means of a porous diffuser at the bottom of the reactor. All the diffusers (cylinder, diameter $2.2 \mathrm{~cm}$, height $2.5 \mathrm{~cm}$, porosity 40\%) were connected to a $138 \mathrm{~W}$ air pump (Sunsun Group Co., Ltd., Zhejiang, China) which provided full mixing and dissolved oxygen (DO) concentration. The dissolved oxygen was controlled at about $6.0 \mathrm{mg} / \mathrm{L}$ via the flow meter (about $200 \mathrm{~mL} / \mathrm{min}$ ) in the reactor. The 12 SGBRs were conducted with a $4 \times 3$ factorial design with a $\mathrm{C} / \mathrm{N}$ ratio $(w / w)$ of $10,15,20$ and 25 , respectively. The reactors were subjected to uninterrupted cycles of $24 \mathrm{~h}$ which consisted of an aerobic feeding phase of $60 \mathrm{~min}$, a mixing phase of $5 \mathrm{~min}, 10 \mathrm{~min}$ collection of the effluent (mixed bioflocs suspension) and the remaining aeration reaction phase. 
After the reactors were set, the nature lake water sample (surface layer, which contained sufficient oxygen to promote microbial growth) was collected from the South Lake, Wuhan city, China $\left(30^{\circ} 28^{\prime} 33^{\prime \prime}\right.$ $\mathrm{N}-114^{\circ} 21^{\prime} 41^{\prime \prime} \mathrm{E}$ ) on 11 December 2017. The concentrations of $\mathrm{TAN}, \mathrm{NO}_{2}{ }^{-} \mathrm{N}, \mathrm{NO}_{3}{ }^{-} \mathrm{N}$, total nitrogen (TN), total phosphorus (TP) and chemical oxygen demand (COD) were $0.54 \mathrm{mg} / \mathrm{L}, 0.02 \mathrm{mg} / \mathrm{L}, 0.2 \mathrm{mg} / \mathrm{L}$, $0.82 \mathrm{mg} / \mathrm{L}, 0.18 \mathrm{mg} / \mathrm{L}$ and $15 \mathrm{mg} / \mathrm{L}$, respectively. Then, $6 \mathrm{~L}$ of natural lake water from the South Lake $\left(30^{\circ} 28^{\prime} 33^{\prime \prime} \mathrm{N}-114^{\circ} 21^{\prime} 41^{\prime \prime} \mathrm{E}\right), \mathrm{NH} 4 \mathrm{Cl}(0.1519 \mathrm{~g})$ and glucose $(0.994 \mathrm{~g}, 1.492 \mathrm{~g}, 1.989 \mathrm{~g}, 2.486 \mathrm{~g})$ were added into the natural wastewater and then added into each reactor to obtain the $\mathrm{C} / \mathrm{N}$ ratios $(w / w)$ of $10: 1,15: 1$, 20:1 and 25:1. The oxygen was introduced into the reactors to start the operation, then the bioflocs were produced by bioflocculation. In each cycle, effluent water samples (mixed bioflocs suspension) of $0.5 \mathrm{~L}$ were collected at 14:00 p.m. every day and then $0.5 \mathrm{~L}$ of the simulative was separately injected into each reactor with an identical metering pump at the flow rate of $0.5 \mathrm{~L} \cdot \mathrm{h}^{-1}$, in order to keep the working volume at $6 \mathrm{~L}$ (if necessary, aeration water was used to supplement volatile water). The $0.5 \mathrm{~L}$ influent

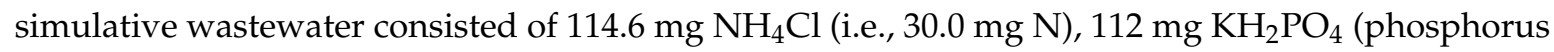
source), $100 \mathrm{mg} \mathrm{MgSO} 4 \cdot 7 \mathrm{H}_{2} \mathrm{O}, 8 \mathrm{mg} \mathrm{CaCl}$ and $160 \mathrm{mg} \mathrm{NaHCO} 3$ (pH buffer). The glucose $\left(\mathrm{C}_{6} \mathrm{H}_{12} \mathrm{O}_{6}\right)$ used as a carbon source was $0.75 \mathrm{~g}, 1.125 \mathrm{~g}, 1.5 \mathrm{~g}$ and $1.875 \mathrm{~g}$ in treatments $\mathrm{C} / \mathrm{N} 10, \mathrm{C} / \mathrm{N} 15, \mathrm{C} / \mathrm{N} 20$ and $\mathrm{C} / \mathrm{N} 25$, respectively. The concentration in the carbon solution depended on the $\mathrm{C} / \mathrm{N}$ ratio $(w / w)$; here, the amount of glucose to be added was calculated based on the TAN concentration in the influent. The calculations were done by following methods described by Hostins [20]. Moreover, each reactor was supplemented with $1 \mathrm{~mL}$ trace element solution every day. The trace element solution contained $3.52 \mathrm{~g} \cdot \mathrm{L}^{-1} \mathrm{FeCl}_{3} \cdot 6 \mathrm{H}_{2} \mathrm{O}, 0.36 \mathrm{~g} \cdot \mathrm{L}^{-1} \mathrm{MnCl}_{2} \cdot 4 \mathrm{H}_{2} \mathrm{O}, 0.08 \mathrm{~g} \cdot \mathrm{L}^{-1} \mathrm{CuSO}_{4} \cdot 5 \mathrm{H}_{2} \mathrm{O}, 0.30 \mathrm{~g} \cdot \mathrm{L}^{-1} \mathrm{ZnSO}_{4} \cdot 7 \mathrm{H}_{2} \mathrm{O}$ and $0.38 \mathrm{~g} \cdot \mathrm{L}^{-1} \mathrm{CoCl}_{2} \cdot 6 \mathrm{H}_{2} \mathrm{O}$ [22].

\subsection{Analysis of Water Samples}

The $0.5 \mathrm{~L}$ effluent was filtered under vacuum pressure through $0.45 \mu \mathrm{m}$ fiber filter paper then used for water sample analysis. The indices of water samples, including TAN, nitrite nitrogen $\left(\mathrm{NO}_{2}{ }^{-} \mathrm{N}\right)$, nitrate nitrogen $\left(\mathrm{NO}_{3}{ }^{-} \mathrm{N}\right)$, total nitrogen (TN) and total phosphorus (TP) were measured in accordance with the standard methods [23]. COD was determined using a COD analyzer (AQ4001; Thermo, MA, USA). DO, total dissolved solids (TDS), $\mathrm{pH}$ and temperature were measured in-situ at 13:40 every day using a multi-parameter YSI Professional Plus handheld water quality sonde (Yellow Spring, $\mathrm{OH}$, USA). All samples were analyzed in triplicate and reported. Statistical analyses were performed using SPSS v19.0. Statistical significance was set at a $p$-value less than 0.05 .

\subsection{TAN Removal Tracking Test}

In order to observe the conversion of TAN in one cycle and investigate the main ways of removing TAN, the TAN removal tracking test was performed. At the stage of stable growth of bioflocs (day 18), determined according to the accumulation of bioflocs volume (BFV), the TAN removal tracking test was performed. On day 18, after the influent was added to the reactor, $20 \mathrm{~mL}$ effluent from each reactor was taken every $3 \mathrm{~h}$ in one cycle $(24 \mathrm{~h})$ until 14:00 on the following day. Then some indicators were measured, including COD, TAN, nitrite nitrogen $\left(\mathrm{NO}_{2}{ }^{-}-\mathrm{N}\right)$, nitrate nitrogen $\left(\mathrm{NO}_{3}{ }^{-}-\mathrm{N}\right)$, temperature (T) and DO.

\subsection{Bioflocs Parameters and Measurement of Biomass}

An Imhoff cone (1000-0010, Nalgene) was used to determine the bioflocs volume (BFV) which reflected the volume occupied by the flocs in $1 \mathrm{~L}$ of reactor water after $30 \mathrm{~min}$ of sedimentation [19]. Total suspended solids (TSS) were analyzed following the standard methods for water and wastewater analysis [23]. After the effluent was filtered, the TSS which contained the complete biomass on the fiber filter paper were reclaimed, air-dried and dried in an oven at $105{ }^{\circ} \mathrm{C}$ (constant weight). The protein contents of biomass were determined in order to measure the nutritional indicators of biomass. The sludge volume index (SVI) was defined as the volume in $\mathrm{mL}$ occupied by $1 \mathrm{~g}$ of TSS after 
settling. Finally, pooled samples were ground and measured by biochemical composition analysis using standard methods [24].

\subsection{DNA Extraction and High-Throughput Sequencing of $16 \mathrm{~S}$ rRNA}

Water samples from the four treatments were collected and analyzed by Illumina MiSeq sequencing of $16 \mathrm{~S}$ rRNA on day 1 (PP, primeval period, DNA sample named P0), day 9, day 19 and day 29, in order to obtain an entire understanding of the evolvement of the bacterial community structure resulting from different $\mathrm{C} / \mathrm{N}$ ratios. Therefore, the entire experimental cycle was divided into three periods: grow period (GP): day 1 to day 9; treatment period (TP): day 10 to day 19; finish period (FP): day 20 to day 29. DNA samples were extracted at the end of each period, and named G1-G4, T1-T4 and F1-F4; the sequence of ordinal numbers represents treatments $C / N 10, C / N ~ 15, C / N ~ 20$ and C/N 25, respectively. Every time the DNA samples were extracted, a total of 12 water samples (approximately $100 \mathrm{~mL}$ ) from 12 reactors were collected and mixed to 4 samples according to the different treatments. DNA samples from water-dwelling microorganisms were extracted as described by Lu [25]. The concentration and purification of DNA were determined by NanoDrop ND-2000c (Theromo Fisher Scientific, Waltham, MA, USA), and DNA quality was checked by $1 \%$ agarose gel electrophoresis. DNA samples were stored at $-80^{\circ} \mathrm{C}$ for subsequent analysis.

The V3-V4 hypervariable regions of the bacteria 16S rRNA gene were amplified with the forward primers 338F (5'-ACTCCTACGGGAGGCAGCAG-3') and the reverse primer 806R (5'-GGACTACHVGGGTWTCTAAT-3') by thermocycler PCR system (GeneAmp 9700, ABI, MA, USA) [26]. The PCR reactions were conducted using the following program: $3 \mathrm{~min}$ of denaturation at $95^{\circ} \mathrm{C}, 30$ cycles of $30 \mathrm{~s}$ at $95^{\circ} \mathrm{C}, 30 \mathrm{~s}$ for annealing at $55^{\circ} \mathrm{C}$, and $45 \mathrm{~s}$ for elongation at $72{ }^{\circ} \mathrm{C}$, and a final extension at $72{ }^{\circ} \mathrm{C}$ for $10 \mathrm{~min}$ and $10^{\circ} \mathrm{C}$ until halted by user. The PCR reactions were performed in triplicate using a $20 \mu \mathrm{L}$ mixture containing $4 \mu \mathrm{L}$ of $5 \times$ FastPfu buffer, $2 \mu \mathrm{L}$ of $2.5 \mathrm{mM}$ dNTPs, $0.8 \mu \mathrm{L}$ of each primer $(5 \mu \mathrm{M}), 0.4 \mu \mathrm{L}$ of FastPfu polymerase and $10 \mathrm{ng}$ of template DNA. The $\mathrm{ddH}_{2} \mathrm{O}$ was added to keep the final volume at $20 \mu \mathrm{L}$. The resulting PCR products were extracted from a $2 \%$ agarose gel and further purified using the AxyPrep DNA Gel Extraction Kit (Axygen Biosciences, Union City, CA, USA) and quantified using QuantiFluor ${ }^{\mathrm{TM}}$-ST (Promega, Madison, WI, USA) according to the manufacturer's protocol. Purified amplicons were pooled in an equimolar manner and paired-end sequenced $(2 \times 300)$ on an Illumina MiSeq platform (Illumina, San Diego, CA, USA) according to the standard protocols by Majorbio Bio-Pharm Technology Co., Ltd. (Shanghai, China).

\subsection{Microbial Community Diversity Analysis}

The raw fastq files were demultiplexed, quality-filtered by Trimmomatic and merged by FLASH with the following criteria. Firstly, the 468-bp (total bacteria) reads were truncated at any site receiving an average quality score $<20$ over a $50 \mathrm{bp}$ sliding window. Secondly, primers were exactly matched allowing 2 nucleotide mismatching and reads containing ambiguous bases were removed. Thirdly, sequences whose overlap was longer than $10 \mathrm{bp}$ were merged according to their overlap sequence. Reads that could not be assembled were discarded before further analyses. Operational taxonomic units (OTUs) were clustered with $97 \%$ similarity cutoff using UPARSE (version 7.1) and chimeric sequences were identified and removed using UCHIME. The diversity indices, species richness (ACE, Chao 1 and Shannon index) and rarefaction curves were determined based on the calculated OTUs [27]. The taxonomy of each 16S rRNA gene sequence was analyzed by the RDP Classifier algorithm against the Silva (SSU123) 16S rRNA database using a confidence threshold of 70\%. The raw reads were deposited into the NCBI Sequence Read Archive (SRA) database (accession number: SRP 150395). 


\section{Results}

\subsection{Reactor Performance for Treating Simulative Wastewater}

The SGBRs were operated for 31 days under conditions of $24 \mathrm{~h}$ lighting with daily testing of environmental physical indicators as shown in Table 1 . DO levels remained stable around $6 \mathrm{mg} \cdot \mathrm{L}^{-1}$, which was suitable for cultivating bioflocs [12]. The $\mathrm{pH}$ decreased at the later stage of the experiment in all treatments. In treatment C/N 10, the TDS was higher than other treatments, presumably due to the relatively high inorganic content (TN, TP) in the effluent.

Table 1. Water quality parameters of the influent and effluent of the reactors at different $\mathrm{C} / \mathrm{N}$ ratios (mean \pm standard deviation).

\begin{tabular}{|c|c|c|c|c|}
\hline & $\mathrm{C} / \mathrm{N} 10$ & $\mathrm{C} / \mathrm{N} 15$ & $\mathrm{C} / \mathrm{N} 20$ & $\mathrm{C} / \mathrm{N} 25$ \\
\hline 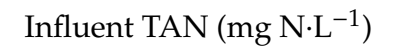 & $30 \pm 0.6$ & $29 \pm 1.1$ & $29 \pm 0.9$ & $30 \pm 0.7$ \\
\hline Effluent TAN (mg N.L $\left.\mathrm{L}^{-1}\right)$ & $8.37 \pm 1.30^{\mathrm{a}}$ & $2.76 \pm 1.55^{b}$ & $0.84 \pm 1.55^{c}$ & $0.58 \pm 1.45^{c}$ \\
\hline Effluent $\mathrm{NO}_{2}{ }^{-}-\mathrm{N}\left(\mathrm{mg} \mathrm{N} \cdot \mathrm{L}^{-1}\right)$ & $0.90 \pm 0.48^{\mathrm{a}}$ & $0.12 \pm 0.08^{b}$ & $0.04 \pm 0.06^{b}$ & $0.02 \pm 0.05^{b}$ \\
\hline Effluent $\mathrm{NO}_{3}{ }^{-}-\mathrm{N}\left(\mathrm{mgN} \cdot \mathrm{L}^{-1}\right)$ & $0.24 \pm 0.03^{\mathrm{a}}$ & $0.13 \pm 0.04^{b}$ & $0.12 \pm 0.02^{b}$ & $0.12 \pm 0.02^{b}$ \\
\hline Effluent COD $\left(\mathrm{mg} \cdot \mathrm{L}^{-1}\right)$ & $59.38 \pm 26.59^{a}$ & $83.58 \pm 16.26^{b}$ & $65.15 \pm 23.30 \mathrm{bc}$ & $72.26 \pm 22.23$ \\
\hline Effluent TN (mg N.L $\left.\mathrm{L}^{-1}\right)$ & $9.57 \pm 1.86^{\mathrm{a}}$ & $3.42 \pm 1.50^{b}$ & $0.97 \pm 1.60^{c}$ & $0.69 \pm 1.54^{\mathrm{c}}$ \\
\hline TAN removal efficiency (\%) & $37.4 \pm 6.3^{\mathrm{a}}$ & $68.2 \pm 9.9^{b}$ & $91.3 \pm 8.3^{c}$ & $94.6 \pm 3.8^{c}$ \\
\hline $\mathrm{pH}$ & $8.31 \pm 0.19^{a}$ & $8.24 \pm 0.19^{a}$ & $8.24 \pm 0.19^{a}$ & $8.21 \pm 0.16^{a}$ \\
\hline $\mathrm{DO}\left(\mathrm{mg} \cdot \mathrm{L}^{-1}\right)$ & $6.2 \pm 0.5$ & $5.9 \pm 0.8$ & $6.1 \pm 0.6$ & $6.0 \pm 0.7$ \\
\hline $\operatorname{TDS}\left(\mathrm{mg} \cdot \mathrm{L}^{-1}\right)$ & $503.7 \pm 17.2^{\mathrm{a}}$ & $485.4 \pm 13.3^{c}$ & $475.5 \pm 9.8^{b}$ & $486.6 \pm 14.4^{\mathrm{C}}$ \\
\hline
\end{tabular}

Different lowercase letters indicate significant differences between treatments at the $p<0.05$ level (one-way ANOVA and Tukey's Honestly Significant Difference (HSD) test) $(n=31)$. Abbreviations: TAN, total ammonia nitrogen; $\mathrm{NO}_{2}{ }^{-} \mathrm{N}$, nitrite nitrogen; $\mathrm{NO}_{3}{ }^{-} \mathrm{N}$, nitrate nitrogen; chemical oxygen demand (COD); $\mathrm{TN}$, total nitrogen; $\mathrm{DO}$, dissolved oxygen; TDS, total dissolved solids.

As shown in Table 1, the effluent TAN in treatments C/N 15, C/N 20 and C/N 25 was significantly lower $(p<0.05)$ than those in the treatment $\mathrm{C} / \mathrm{N} 10$. After the addition of simulative wastewater, the effluent TAN changed significantly; treatments of C/N 20 and C/N 25 showed good TAN removal performance, while the effluent TAN concentrations of $9.33 \pm 0.11$ and $2.12 \pm 0.08 \mathrm{mg} \cdot \mathrm{L}^{-1}$ still remained in treatments $\mathrm{C} / \mathrm{N} 10$ and $\mathrm{C} / \mathrm{N} 15$ (Figure 1a). This phenomenon was similar to the study of Zhao [6], in which increasing the $\mathrm{C} / \mathrm{N}$ ratio can effectively reduce ammonia nitrogen levels. The fluctuation of $\mathrm{TN}$ was very similar to the change of TAN. The effluent $\mathrm{NO}_{2}{ }^{-}-\mathrm{N}$ in treatment $\mathrm{C} / \mathrm{N} 10$ continued to accumulate throughout the experiment and was significantly $(p<0.05)$ different from other treatments (Figure $1 b)$. The effluent nitrate nitrogen $\left(\mathrm{NO}_{3}{ }^{-}-\mathrm{N}\right)$ in all treatments was slow to accumulate, and presumably nitrification occurred during bioflocs formation. Throughout the experiment, the TP of effluent fluctuations are shown in Figure 1c. During the first 29 days of the experimental period (stage 1), the simulative wastewater influent followed Table 1; however, after the 29th day, the addition of phosphate was removed until the end of the experiment (stage 2). At stage 1, in all treatments, the addition of phosphate caused continuous fluctuating growth of TP in the effluent. Then, the TP of the effluent unexpectedly dropped at stage 2 in all the treatments. This explained that bioflocs had a great positive effect on the removal of phosphorus compounds, and the growth of heterotrophic microorganisms ingested phosphorus in the reactor water [12]. The COD removal efficiency in treatments $\mathrm{C} / \mathrm{N} 10, \mathrm{C} / \mathrm{N} 15, \mathrm{C} / \mathrm{N} 20$ and $\mathrm{C} / \mathrm{N} 25$ reached $91.15 \pm 1.03 \%, 91.06 \pm 0.57 \%, 95.09 \pm 0.91 \%$ and $95.53 \pm 0.84 \%$, respectively, at the end of the experiment (Figure 1d). This showed the effectiveness of the reactor for organic removal. 

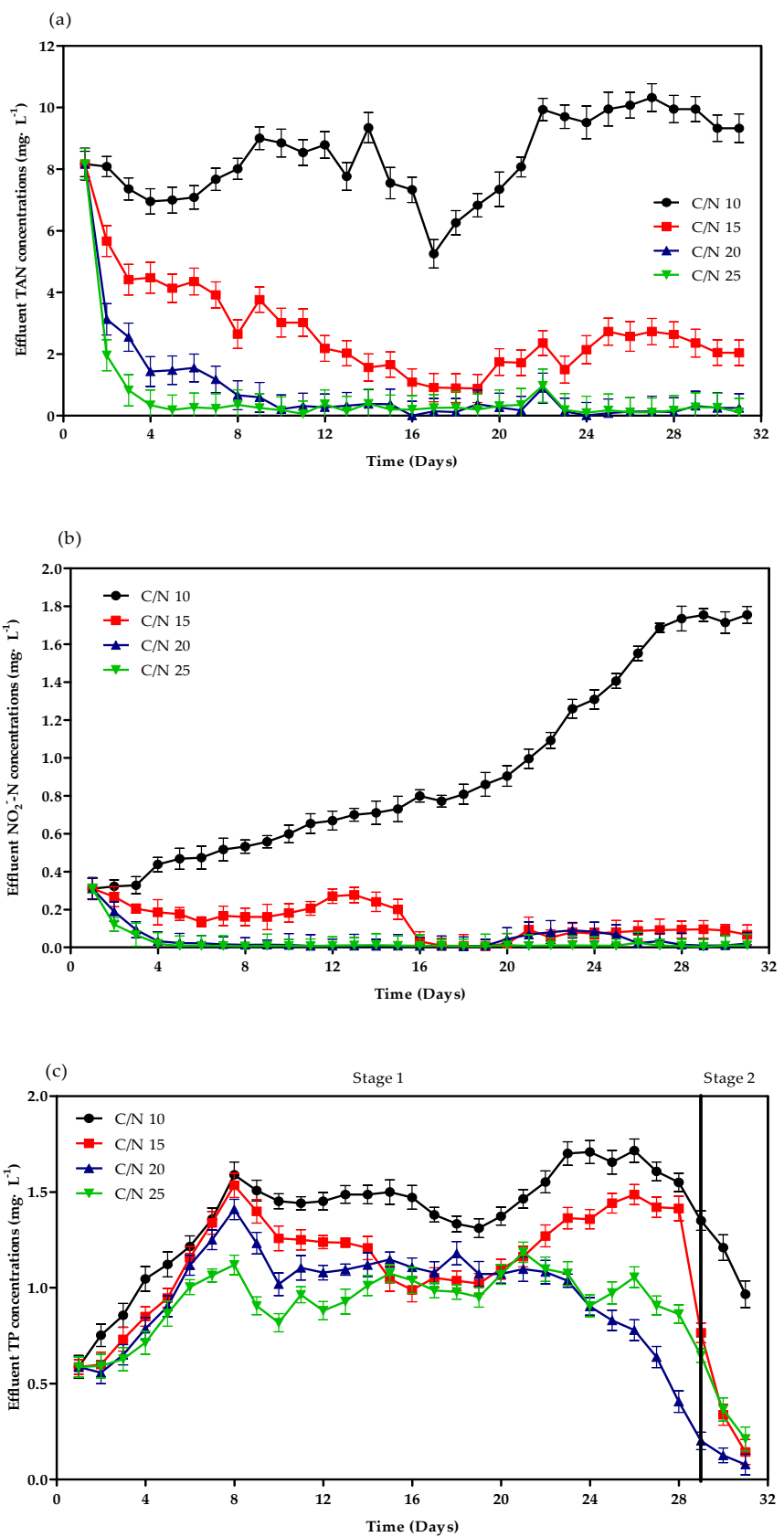

(d)

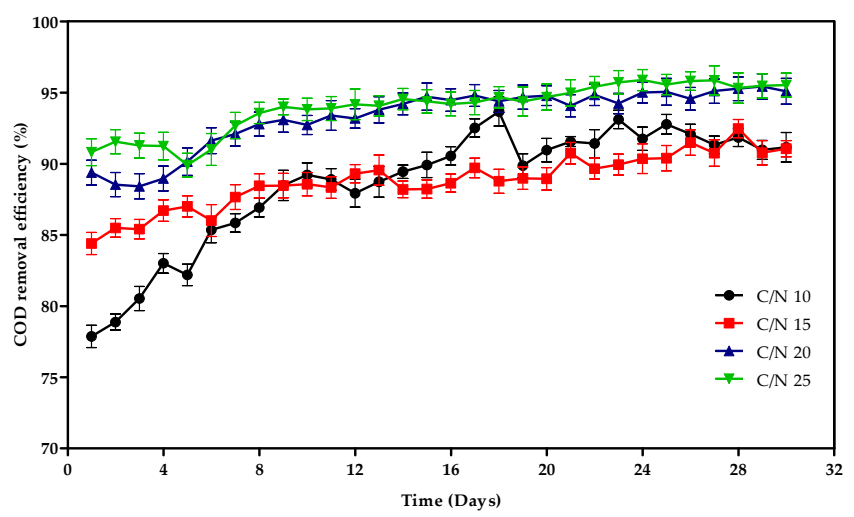

Figure 1. Changes in total ammonia nitrogen (TAN) (a); nitrite $\left(\mathrm{NO}_{2}{ }^{-}-\mathrm{N}\right)$ (b); total phosphorus (TP) (c); and COD removal efficiency (d) of the suspended growth bioreactors at different $\mathrm{C} / \mathrm{N}$ ratio (mean \pm stand deviation). 


\subsection{TAN Removal Tracking Test Analysis}

The fluctuations in effluent chemical indicators ( $\mathrm{COD}, \mathrm{TAN}, \mathrm{NO}_{2}{ }^{-}-\mathrm{N}, \mathrm{NO}_{3}{ }^{-}-\mathrm{N}$ ) and environmental indicators $(\mathrm{T}, \mathrm{DO})$ during a whole cycle under different $\mathrm{C} / \mathrm{N}$ ratios are shown in Figure 2 (temperature not shown). In order to compare the performance of different $\mathrm{C} / \mathrm{N}$ ratio-controlling conditions, an elaborate analysis of the changing trends was implemented. The results exhibited that the varying laws in different $\mathrm{C} / \mathrm{N}$ ratios treatments were similar. According to the previous research results of Yuan [28], a whole cycle can be divided into a satiation stage ( $0 \mathrm{~h}$ to $6 \mathrm{~h})$ and a hunger stage $(6 \mathrm{~h}$ to $24 \mathrm{~h}$ ) according to the characteristic points on TAN and COD.
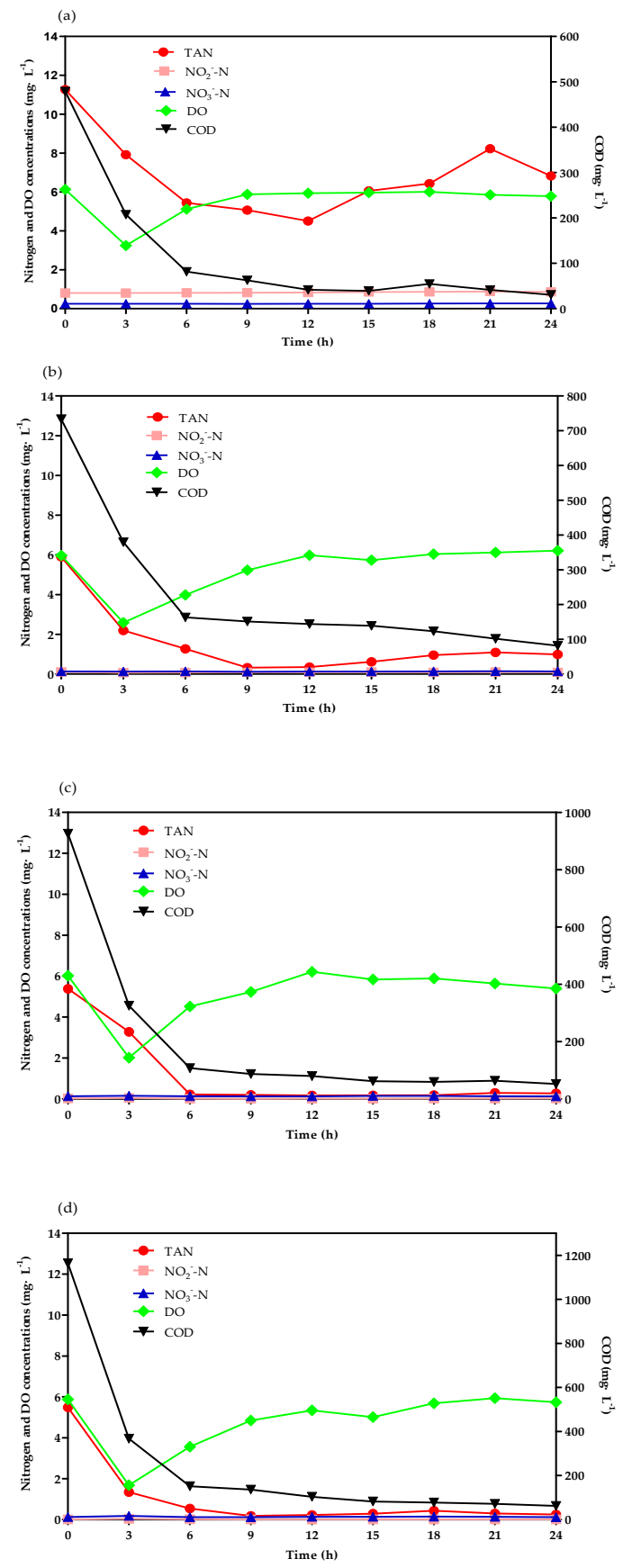

Figure 2. Dynamics of nitrogen concentrations, COD and dissolved oxygen (DO) in the suspended growth bioreactors (SGBRs) of a whole cycle: (a) C/N 10 treatment; (b) C/N 15 treatment; (c) C/N 20 treatment; (d) C/N 25 treatment. 
After the simulative wastewater was added to the SGBRs, adsorption and microbial respiration of heterotrophic microorganisms led to a sharp decrease in organic carbon and TAN in the satiation stage. Simultaneously, DO also declined sharply until it reached the lowest point, and then it turned up. The higher the $\mathrm{C} / \mathrm{N}$ ratio treated, the more DO decreased. In treatments $\mathrm{C} / \mathrm{N} 20$ and $\mathrm{C} / \mathrm{N} 25$, TAN was almost completely consumed, while there were some remnants in treatments $C / N 10$ and $C / N$ 15 , which indicated that different $\mathrm{C} / \mathrm{N}$ ratios have a great effect on the TAN removal process. A large amount of COD was consumed in this stage, which provided nutrition for the growth of heterotrophic microorganisms [28]. During the hunger stage, the TAN in all treatments increased, however, COD was kept at a low level. Throughout the hunger stage, the $\mathrm{NO}_{2}{ }^{-}-\mathrm{N}$ and $\mathrm{NO}_{3}{ }^{-}-\mathrm{N}$ content was always kept at a low level. During the entire tracking test, the TAN removal efficiency in treatments C/N 10, C/N 15, C/N 20 and C/N 25 was $88.67 \%, 94.98 \%, 100.00 \%$ and $100.00 \%$, respectively. The parameters of the latter two treatments were significantly higher than that of the former treatments $(p<0.05)$.

\subsection{Bioflocs Parameters Analysis}

Table 2 shows the bioflocs parameters monitored throughout the experiment. The big standard deviations for the TSS can be ascribed to the continuous increase of biomass. The BFV and TSS in treatments $C / N 15, C / N 20$ and C/N 25 were higher than that in treatment C/N 10, which confirmed the study of $\mathrm{Xu}$ [9]. However, for the SVI, there was no significant difference among the four treatment groups $(p>0.05)$. This fully showed the effect of the $\mathrm{C} / \mathrm{N}$ ratio on the production of biofloc solids. Interestingly, the BFV in all treatments decreased on day 19 and maintained at a stable level. The TSS concentrations on day 31 reached $466.67 \mathrm{mg} \cdot \mathrm{L}^{-1}, 624.13 \mathrm{mg} \cdot \mathrm{L}^{-1}, 652.02 \mathrm{mg} \cdot \mathrm{L}^{-1}$ and $990.73 \mathrm{mg} \cdot \mathrm{L}^{-1}$

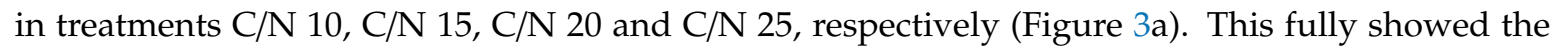
accumulation of biomass. In addition, the concentration of protein followed a similar trend with TSS (Figure 3b), and the steady increase in protein content implied the accumulation of biomass in the SGBRs.

Table 2. Bioflocs parameters (bioflocs volume (BFV), total suspended solids (TSS), sludge volume index (SVI)) in different $\mathrm{C} / \mathrm{N}$ ratios.

\begin{tabular}{|c|c|c|c|c|}
\hline Parameters & $\mathrm{C} / \mathrm{N} 10$ & C/N 15 & C/N 20 & C/N 25 \\
\hline $\mathrm{BFV}\left(\mathrm{mL} \cdot \mathrm{L}^{-1}\right)$ & $18.7 \pm 4.7^{\mathrm{a}}$ & $30.6 \pm 8.5^{b}$ & $36.4 \pm 12.0^{b}$ & $60.0 \pm 15.4^{c}$ \\
\hline $\mathrm{TSS}\left(\mathrm{mg} \cdot \mathrm{L}^{-1}\right)$ & $322.58 \pm 127.51^{\mathrm{a}}$ & $439.11 \pm 167.06^{\mathrm{ab}}$ & $514.61 \pm 177.48^{b}$ & $670.18 \pm 247.35^{c}$ \\
\hline SVI $\left(\mathrm{mL} \cdot \mathrm{g}^{-1}\right)$ & $67.69 \pm 40.95^{a}$ & $80.37 \pm 44.98^{\mathrm{a}}$ & $82.13 \pm 65.23^{a}$ & $91.38 \pm 71.66^{\mathrm{a}}$ \\
\hline
\end{tabular}

Different lowercase letters indicate significant differences between treatments at the $p<0.05$ level (one-way ANOVA and Tukey's HSD test) $(n=26)$.

\subsection{Microbial Community Dynamics}

\subsubsection{Preliminary Analysis of $16 \mathrm{~S}$ rRNA Sequencing}

In order to get a deeper insight into changes in the bacterial community structures with different $\mathrm{C} / \mathrm{N}$ ratio treatments during the experiment, $16 \mathrm{~S}$ rRNA sequencing was implemented. A total of $1,859,030$ high-quality sequencing contigs (average $439 \mathrm{bp}$ ) were obtained for 39 samples. These high-quality sequencing contigs were normalized to 32,387 for each sample and were performed for further analysis. At $97 \%$ similarity level, these contigs were identified and accurately clustered into 1201 operational taxonomic units (OTUs). All species were covered according to the coverage indices and rarefaction curves (Figure S1 in SM). The Shannon diversity index reflected community diversity in samples; samples P0, T1, F1, F2 had a lower Shannon index than that of other samples indicating community diversity would enhance along with the increasing $\mathrm{C} / \mathrm{N}$ ratio. The Simpson indices also validated this result (the higher Simpson index values, the lower community diversity) (as shown in Table S1 in SM). The OTUs, Chao1 and ACE in G1-G4, T1-T4 and F2-F4 have a significant difference with P0 $(p<0.05)$. This showed that the addition of simulative wastewater increases the community 
richness, because the addition of an extra carbon source stimulated the proliferation of microorganisms, and an elevated $\mathrm{C} / \mathrm{N}$ ratio increased microbial diversity.

(a)

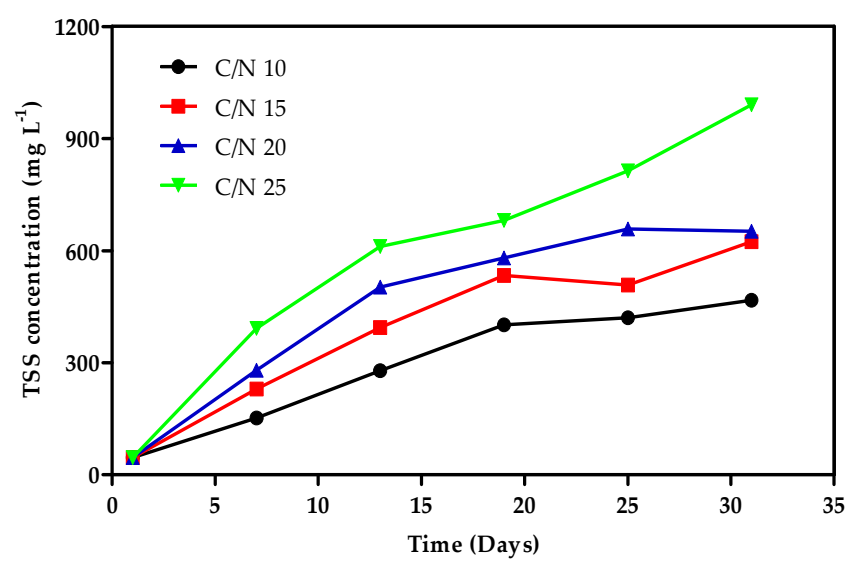

(b)

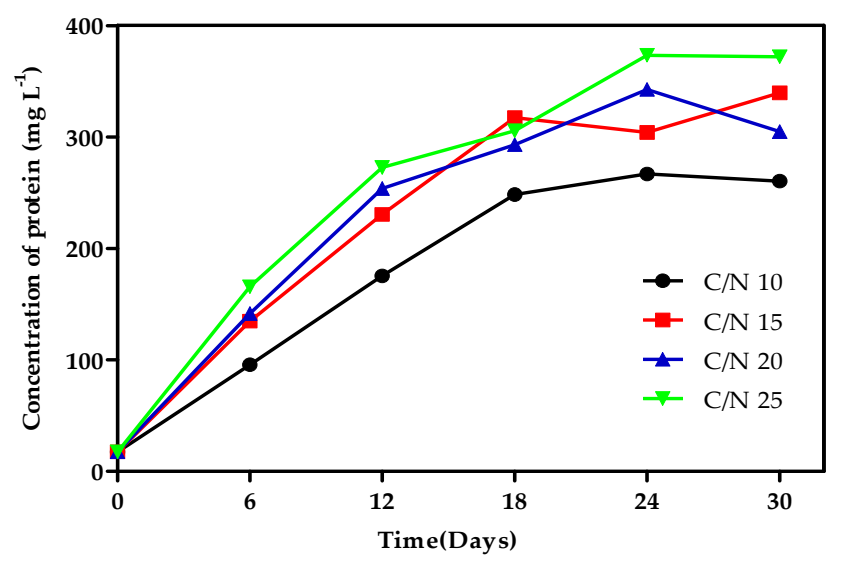

Figure 3. The TSS concentration (a) and concentration of protein (b) in different $\mathrm{C} / \mathrm{N}$ ratios.

\subsubsection{Evolution of Bacterial Community Structure}

Within the bacterial community, 24 phyla were found among all samples during the different time-lapse samples. The predominant phyla were shown in Figure 4a. During the entire experiment, the predominant and common shared phyla in the BFT systems were Proteobacteria $(22.49 \%-67.34 \%)$, Bacteroidetes (6\%-35.26\%) and Verrucomicrobia (1.62\%-9.51\%). The abundance of Proteobacteria and Bacteroidetes in all treatments decreased at the TP and the FP, but in treatments $\mathrm{C} / \mathrm{N} 10$ and $\mathrm{C} / \mathrm{N} 15$ they decreased more significantly than in treatments $\mathrm{C} / \mathrm{N} 20$ and $\mathrm{C} / \mathrm{N} 25(p<0.05)$. The abundance of Verrucomicrobia in treatments $\mathrm{C} / \mathrm{N} 20$ and C/N 25 was higher than in other treatments. The abundance of Actinobacteria continued to increase among all samples during the experiment, but the abundance of Cyanobacteria and Chlorobi obviously fluctuated. Unexpectedly, Saccharibacteria appeared in all treatments at the $\mathrm{TP}$, reaching $57.20 \%$ in $\mathrm{C} / \mathrm{N} 10$ and $19.36 \%$ in $\mathrm{C} / \mathrm{N} 15$; yet it was relatively less in treatments C/N $20(2.45 \%)$ and C/N 25 (1.39\%). However, at the FP, the abundance of Saccharibacteria significantly increased in all treatments (>23.5\%). The Saccharibacteria (former candidate division TM7, also called candidate phylum Saccharibacteria) is frequently found in various natural environments and activated sludge which made it a beneficial candidate phylum [29]. 

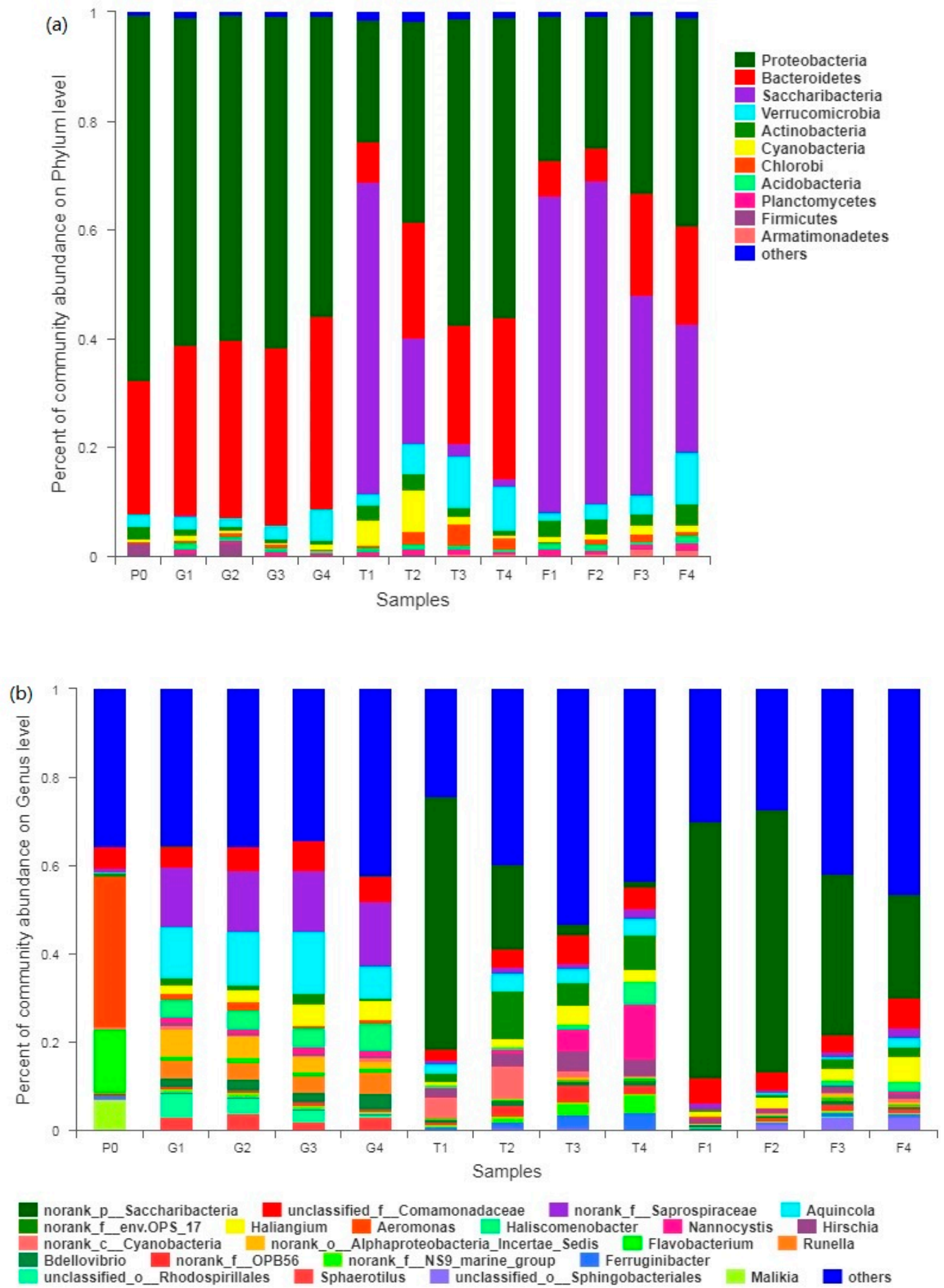

Figure 4. Bar profiling graphs of all samples (each bar shows the average of three parallel samples) at phylum (a) level and genus (b) level (dominating phyla $>1 \%$ in one sample, dominating genus $>3 \%$ in one sample). P0: day 1; G1-G4: day 9, the sequence of ordinal numbers represents treatments C/N 10, C/N 15, C/N 20 and C/N 25, respectively. Same as below; T1-T4: day 19, F1-F4: day 29.

As shown in Figure $4 \mathrm{~b}$, the bacterial communities at the genus level were investigated in order to better understand microbial diversity in the SGBR systems. Surprisingly, there were many unclassified and no rank sequences at the genus level which explained the complexity and unknown aspects of the microbial communities in the reactors. Some highly abundant bacteria such as unclassified_f_Comamonadaceae, norank_c_env.OPS_17 and norank_f_Saprospiraceae were also 
included and were likely to play significant roles in the SGBR system as the environmental bacteria. The predominant genera were Aquincola, Aeromonas, Flavobacterium, Haliangium, Haliscomenobacter, Nannocystis and Bdellovibrio. Aquincola, Haliangium and Haliscomenobacter were not detected in the P0 sample, but as the experiment progressed, they became dominant genus. In treatments C/N 20 and $\mathrm{C} / \mathrm{N} 25$, the abundance of Haliangium and Haliscomenobacter were higher than that in the treatments $\mathrm{C} / \mathrm{N} 10$ and $\mathrm{C} / \mathrm{N} 15$, but Aquincola seemed to have no significant difference in all treatments. Many pathogens, such as Aeromonas, Acidovorax, Flavobacterium and Malikia were significantly decreased in GP, TP and FP; especially Aeromonas and Flavobacterium, which had an absolute advantage in the P0 sample, but then almost disappeared. Nannocystis had the highest abundance in samples T3 and T4, and low abundance in other samples. Overall, the higher $\mathrm{C} / \mathrm{N}$ treatments maintained better microbial diversity and stability than lower $\mathrm{C} / \mathrm{N}$ treatments.

\subsubsection{Microbial Community Cluster Analysis}

In order to gain a deeper understanding of the evolution of microbial communities in different treatments, principal component analysis (PCA) was implemented to analyze sequencing tags at the OTU level (Figure 5) where each point represented one sample. Along the PC1 vector, similar bacterial communities were observed for samples of T3, T4, PP and GP, while the samples of T1, T2, F1 and F2 were far away. This showed that the cultivation time had a great influence on the microbial community structure of bioflocs. Along the PC2 vector, similar bacterial communities were observed for samples in PP and GP, which shows that the microbial community changes at the beginning of the experiment. As the experiment progresses, the microbial community structure in all treatments gradually changes and then stabilizes. The changes in the TP sample were the most obvious. The microbial community in treatments $\mathrm{C} / \mathrm{N} 15$ and $\mathrm{C} / \mathrm{N} 25$ were more stable than $\mathrm{C} / \mathrm{N} 10$ and $\mathrm{C} / \mathrm{N} 15$.

\section{PCA on OTU level}

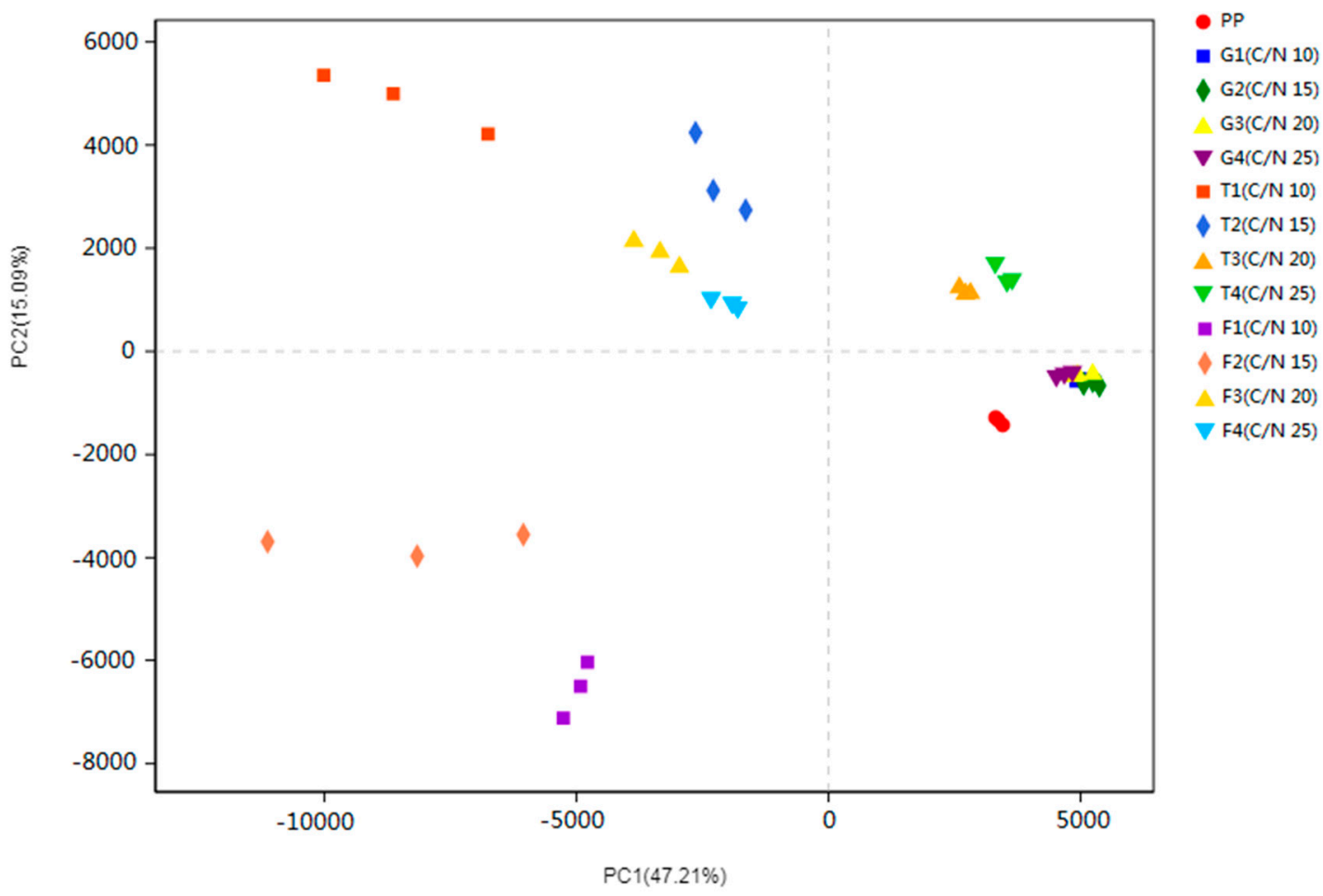

Figure 5. Principal component analysis (PCA) of bacterial community composition (operational taxonomic unit (OTU) level), PP: primeval period; G1 (C/N 10) represents the treatment of C/N 10 in GP, similarly, and so on. 


\section{Discussion}

\subsection{Physicochemical Indicators in SGBRs}

The performance of SGBRs was constrained by a variety of environmental factors, such as DO, $\mathrm{pH}$ and temperature. Adequate DO was essential for aerobic heterotrophic microorganisms which were the main body of the biofloc [1]. Wasielesky [30] investigated the proliferation of a heterotrophic microbial community and determined that as the concentration of carbon dioxide increases in a limited water exchange system, the $\mathrm{pH}$ would reduce. In SGBRs, due to the addition of a $\mathrm{pH}$ buffer, the difference in $\mathrm{pH}$ of treatments in the reactors was not significant and remained stable. Each reactor was operated at a constant stable temperature of $26 \pm 1{ }^{\circ} \mathrm{C}$ which was thought to be favorable for the growth of bioflocs [6,31]. In SGBRs, increasing the C/N ratio can indeed greatly reduce TAN in wastewater, which accorded with the theoretical prediction made by Avnimelech [5]. However, the removal efficiency of TAN was not significant $(p>0.05)$ once the $\mathrm{C} / \mathrm{N}$ ratio exceeds 20 ; in treatments $\mathrm{C} / \mathrm{N} 20$ and $\mathrm{C} / \mathrm{N} 25$, the results were $91.3 \pm 8.3 \%$ and $94.6 \pm 3.8 \%$, respectively (Table 1 ). At the beginning of the experiment, in the case of C/N 10, the heterotrophic microorganisms in the bioflocs were grown and propagated using organic carbon sources, and the biomass increased continuously (the concentration of TSS continued to accumulate). Until the middle of the experiment (about 16 days), the input organic carbon source is insufficient to meet the needs of heterotrophic microorganisms in the C/N 10 treatment, and decomposition of microbial death led to an increase in TAN concentration [32]; since then, the rate of growth of TSS concentration slowed down (Figure 3a). The other treatments had relatively sufficient organic carbon sources, so the TAN concentration was less accumulated. Due to the dependence of carbon, nitrogen removal efficiencies were limited in treatments $C / N 10$ and $C / N$ 15 , but with the increasing $\mathrm{C} / \mathrm{N}$ ratio, the TAN was the limiting factor. In treatment $\mathrm{C} / \mathrm{N} 10, \mathrm{NO}_{2}{ }^{-}-\mathrm{N}$ had obvious accumulation, which may be due to the higher nitrification rate using internal carbon sources than that of denitrification [33-35]. Previous research showed that nitrate-reducing bacteria are more competitive with carbon sources than nitrite-reducing bacteria, thus the lack of a carbon source would cease nitrite accumulation [36]. Glucose as the sole carbon source was also an influencing factor. In treatments $\mathrm{C} / \mathrm{N} 15, \mathrm{C} / \mathrm{N} 20$ and $\mathrm{C} / \mathrm{N} 25$, when TAN was significantly reduced, there was subtle accumulation of $\mathrm{NO}_{2}{ }^{-}-\mathrm{N}$ and $\mathrm{NO}_{3}{ }^{-}-\mathrm{N}$, and at the same time, TSS grew significantly (Figure 3a). Nitrogen removal in SGBRs was correlated with the bacterial community structure. In this study, the significant increase of diversity in GP, TP and FP suggested significant changes in community structure, which should be responsible for nitrogen removal in SGBRs. These indicated that immobilization of heterotrophic bacteria should be encouraged in high $\mathrm{C} / \mathrm{N}$ ratio treatments. The SGBRs showed excellent COD removal performance, because the growth of bioflocs consumed the organic matter in the reactor [6]. The results showed that an elevated $\mathrm{C} / \mathrm{N}$ ratio promoted the removal of TAN and COD. Bioflocs consisted of heterotrophic organisms, algae, protozoa and organic debris [13], therefore, decomposition or proliferation required the provision of organic matter. In addition, the change of TP explained that bioflocs had a great positive effect on the removal of phosphorus compounds [6]. The TP of effluent significantly decreased in stage 2 , and its only conversion pathway was the synthesis of biomass in bioflocs. This study, combined with previous literature, observed the reduction in TAN and $\mathrm{TP}$, an obvious result of the bacterial load [5,37-39].

The TAN removal tracking test was performed in order to observe the conversion of TAN and COD in one cycle. The respiration of heterotrophic microorganisms in mature bioflocs dramatically reduced organic carbon in the satiation stage. Degradation of organic matter produced $\mathrm{CO}_{2}$ resulting in a decrease in $\mathrm{pH}$ and DO in the reactor. Partial TAN was consumed by microorganisms mainly for cell synthesis, because there was no accumulation of $\mathrm{NO}_{2}{ }^{-}-\mathrm{N}$ and $\mathrm{NO}_{3}{ }^{-}-\mathrm{N}$ [28]. Asaduzzaman [15] showed that when there is enough $\mathrm{C} / \mathrm{N}$ ratio, $10 \mathrm{mg} \cdot \mathrm{L}^{-1}$ ammonia nitrogen can be completely transformed through the internal circulation of microorganisms within $5 \mathrm{~h}$, without the accumulation of $\mathrm{NO}_{2}{ }^{-}-\mathrm{N}^{2}$ and $\mathrm{NO}_{3}{ }^{-}-\mathrm{N}$. In the hunger stage, because most organic matter was degraded, continuous aeration caused $\mathrm{CO}_{2}$ to escape from the reactors which led to the $\mathrm{pH}$ rebound. Insufficient organic carbon 
sources limited the removal of TAN from wastewater by heterotrophic microorganisms. As the carbon was degraded, a part of bio-nitrogen may have been converted into TAN again [40]. During the entire tracking test, the physicochemical indicators were analogous in all treatments, which provided a phased reference for the effective reduction of TAN in bioflocs.

\subsection{Bioflocs Parameters Analysis}

BFV is an important indicator to measure the sedimentation properties of bioflocs. The decline of $\mathrm{BFV}$ resulted in the breakdown of aggregate particles, which can be interpreted as both the mixing intensity of water and the presence of microbubbles which contribute to break aggregates, thus speeding up its settlement [41] in the later part of the experiment. It was higher than the TSS concentration of approximately $460 \mathrm{mg} \cdot \mathrm{L}^{-1}$ that was suitable concentration for aquatic animals. Previous research demonstrated that superfluous TSS can be harmful to the production of aquatic animals [17]. It is necessary to collect more suspended effluent from the SGBRs to maintain a lower TSS. For the protein concentration, high carbon to nitrogen ratio input to get more protein, which demonstrated the potential of bioflocs as aquafeeds.

\subsection{Evolution of Bacterial Community Structure}

In this study, the predominant phyla were Proteobacteria, Bacteroidetes and Verrucomicrobia and Actinobacteria, which were the common shared phyla in the BFT systems [19]. Proteobacteria, the most common shared phylum in the BFT systems, played an important role in the assimilation of TAN and the mineralization of organic compounds, especially in the wastewater treatment of bioflocs [42]. Most Proteobacteria are aerobic or facultative. Verrucomicrobia are heterotrophs, which can use various mono, oligo and polysaccharides for growth, which can be multiplied by two divisions and typically found in water or soil [43]. Actinobacteria is regarded as a common probiotic, which can produce beneficial substances in specific environments. Moreover, Actinobacteria helps to decompose the organic matter of dead organisms; they are quite abundant in soil and aquatic sediments where they participate in the decomposition of organic matter [44]. Therefore, the increase of Actinobacteria could be explained by its ability to decompose organic matter which was amplified because of the accumulation of TSS; this may be the reason for the cumulative slowdown of TSS.

Unfortunately, research on the environmental function of Saccharibacteria is insufficient. Saccharibacteria (former candidate division TM7, also called candidate phylum Saccharibacteria) is frequently found in various natural environments and activated sludge which makes it a beneficial candidate phylum [29]. However, Hanada [45] also reported the prevalence of candidate division TM7 in an acidophilic nitrified SBR (sequencing batch reactor) which was added to simulative wastewater made up of ammonium and other salts without a carbon source. Interestingly, Zhao [46] reported that the most suitable salinity for candidate division TM7 is $2 \%$, which is very close to the salinity in the SGBRs. The relative abundance of candidate phylum Saccharibacteria increased with the increasing $\mathrm{N}$ content in soil, which illustrated a preference for candidate Saccharibacteria in ammonia-rich environments $[47,48]$. In our study, the relative abundance of candidate phylum Saccharibacteria was significantly higher in treatments $C / N 10$ and $C / N 15$ than that in treatments $C / N$ 20 and $\mathrm{C} / \mathrm{N} 25$ ( $p<0.05)$. Combined with the results shown in Figure $1 \mathrm{a}$, this phenomenon is similar to that of Eo and Park's research [47]. Hence, its abundance increasing along TAN concentrations suggests that the Saccharibacteria becomes the predominant phylum, which is unfavorable for nitrogen removal in bioflocs. In addition, the rapid proliferation of Saccharibacteria also inevitably reduced the diversity of microbial communities and squeezed the living space of other kinds of microorganisms, especially Proteobacteria and Bacteroidetes.

Some predominant genera were found, such as Aquincola, Aeromonas, Haliangium, Nannocystis and Bdellovibrio. These genera were almost heterotrophic and aerobic, and usually found in environmental communities, such as activated sludge [49]. Aquincola occupied a significant proportion in GP and $\mathrm{TP}$ of the experiment because it of its agglomerating effect and being strictly aerobic. The relative 
abundance of Aquincola decreased in FP as a result of the anaerobic zone formed by the relative volume increase of the bioflocs. In addition, Aeromonas, a type of pathogen, gradually disappeared after the experiment started [50]. Probably due to the complexity of water, there were many unclassified and no rank sequences at the genus level in the analysis of microbial communities. However, different $\mathrm{C} / \mathrm{N}$ ratios had a significant impact on the microbial community structure at the genus level, which explained the selectivity of influent carbon to nitrogen ratio to microbial population. In addition, according to Table S1 in the supplementary data, similar research results also showed that increasing the carbon to nitrogen ratio can increase the diversity of microbial communities [41]. Moreover, as shown in Figure 5, the rate of microbial community structure evolution has gradually slowed down, which indicates the stability of microbial communities in the later stage of the experiment.

\section{Conclusions}

This study showed that an elevated C/N ratio promoted the removal of TAN and COD, and there was no accumulation of nitrite nitrogen and nitrate nitrogen. All treatments showed the same pattern within one cycle; TAN and COD dropped to the lowest level and then increased slightly. Increasing the $\mathrm{C} / \mathrm{N}$ ratio in the influent wastewater could effectively augment the accumulation of biomass in the reactor. Elevated $\mathrm{C} / \mathrm{N}$ ratio increased microbial diversity. The abundance of pathogens in SGBRs was significantly reduced, and surprisingly, Saccharibacteria occupied a dominant position at TP and FP in lower $\mathrm{C} / \mathrm{N}$ ratio treatments $(\mathrm{C} / \mathrm{N} 10$ and $\mathrm{C} / \mathrm{N} 15)$, which may be related to the accumulation of TAN.

Supplementary Materials: The following are available online at http://www.mdpi.com/2073-4441/11/8/1640/s1.

Author Contributions: All authors listed have contributed to this study. Conceptualization, X.H. and J.G.; methodology, C.U.H.; software, M.D. and J.C.; validation, J.H., D.L. and X.H.; formal analysis, J.G.; investigation, C.U.H.; writing—original draft preparation, X.H.; writing—review and editing, X.H.

Funding: This research was funded by the Fundamental Research Funds for Innovation Center of Hubei Province (2016ZXPY02) and the Earmarked Fund for China Agriculture Research System (Project CARS-45).

Conflicts of Interest: The authors declare no conflicts of interest.

\section{References}

1. Crab, R.; Defoirdt, T.; Bossier, P.; Verstraete, W. Biofloc technology in aquaculture: Beneficial effects and future challenges. Aquaculture 2012, 356, 351-356. [CrossRef]

2. Kuhn, D.D.; Lawrence, A.L.; Crockett, J.; Taylor, D. Evaluation of bioflocs derived from confectionary food effluent water as a replacement feed ingredient for fishmeal or soy meal for shrimp. Aquaculture 2016, 454, 66-71. [CrossRef]

3. Luo, G.Z.; Zhang, N.; Tan, H.X.; Hou, Z.W.; Liu, W.C. Efficiency of producing bioflocs with aquaculture waste by using poly-hydroxybutyric acid as a carbon source in suspended growth bioreactors. Aquac. Eng. 2017, 76, 34-40. [CrossRef]

4. Xu, W.J.; Morris, T.C.; Samocha, T.M. Effects of C/N ratio on biofloc development, water quality, and performance of Litopenaeus vannamei juveniles in a biofloc-based, high-density, zero-exchange, outdoor tank system. Aquaculture 2016, 453, 169-175. [CrossRef]

5. Avnimelech, Y. C/N ratio as a control element in aquaculture systems. Aquaculture 1999, 176, $227-235$. [CrossRef]

6. Zhao, Z.G.; Xu, Q.Y.; Luo, L.; Wang, C.A.; Li, J.N.; Wang, L.S. Effect of feed C/N ratio promoted bioflocs on water quality and production performance of bottom and filter feeder carp in minimum-water exchanged pond polyculture system. Aquaculture 2014, 434, 442-448. [CrossRef]

7. Da Silva, K.R.; Wasielesky, W.J.; Abreu, P.C. Nitrogen and phosphorus dynamics in the biofloc production of the Pacific white shrimp, Litopenaeus vannamei. J. World Aquacult. Soc. 2013, 44, 30-41. [CrossRef]

8. Hargreaves, J.A. Photosynthetic suspended-growth systems in aquaculture. Aquac. Eng. 2006, 34, $344-363$. [CrossRef] 
9. $\mathrm{Xu}$, W.J.; Morris, T.C.; Samocha, T.M. Effects of two commercial feeds for semi-intensive and hyper-intensive culture and four $\mathrm{C} / \mathrm{N}$ ratios on water quality and performance of Litopenaeus vannamei juveniles at high density in biofloc-based, zero-exchange outdoor tanks. Aquaculture 2018, 490, 194-202. [CrossRef]

10. Crab, R.; Chielens, B.; Wille, M.; Bossier, P.; Verstraete, W. The effect of different carbon sources on the nutritional value of bioflocs, a feed for Macrobrachium rosenbergii postlarvae. Aquac. Res. 2010, 41, 559-567. [CrossRef]

11. Wei, Y.F.; Liao, S.A.; Wang, A.L. The effect of different carbon sources on the nutritional composition, microbial community and structure of bioflocs. Aquaculture 2016, 465, 88-93. [CrossRef]

12. Azim, M.E.; Little, D.C.; Bron, J.E. Microbial protein production in activated suspension tanks manipulating C: $\mathrm{N}$ ratio in feed and the implications for fish culture. Bioresour. Technol. 2007, 99, 3590-3599. [CrossRef] [PubMed]

13. De Schryver, P.; Verstraete, W. Nitrogen removal from aquaculture pond water by heterotrophic nitrogen assimilation in lab-scale sequencing batch reactors. Bioresour. Technol. 2009, 100, 1162-1167. [CrossRef] [PubMed]

14. Schneider, O.; Sereti, V.; Eding, E.H.; Verreth, J.A.J. Heterotrophic bacterial production on solid fish waste: TAN and nitrate as nitrogen source under practical RAS conditions. Bioresour. Technol. 2007, 98, 1924-1930. [CrossRef] [PubMed]

15. Asaduzzaman, M.; Wahab, M.A.; Verdegem, M.C.J.; Huque, S.; Salam, M.A.; Azim, M.E. C/N ratio control and substrate addition for periphyton development jointly enhance freshwater prawn Macrobrachium rosenbergii production in ponds. Aquaculture 2008, 280, 117-123. [CrossRef]

16. De Schryver, P.; Crab, R.; Defoirdt, T.; Boon, N.; Verstraete, W. The basics of bioflocs technology: The added value for aquaculture. Aquaculture 2008, 277, 125-137. [CrossRef]

17. Ray, A.J.; Lewis, B.L.; Browdy, C.L.; Leffler, J.W. Suspended solids removal to improve shrimp (Litopenaeus vannamei) production and an evaluation of a plant-based feed in minimal-exchange, superintensive culture systems. Aquaculture 2010, 299, 89-98. [CrossRef]

18. Martínez-Córdova, L.R.; Martínez-Porchas, M.; Emerenciano, M.G.C.; Miranda-Baeza, A.; Gollas-Galván, T. From microbes to fish the next revolution in food production. Crit. Rev. Biotechnol. 2016, 37, 287-295. [CrossRef]

19. Deng, M.; Chen, J.Y.; Gou, J.W.; Hou, J.; Li, D.P.; He, X.G. The effect of different carbon sources on water quality, microbial community and structure of biofloc systems. Aquaculture 2018, 482, 103-110. [CrossRef]

20. Hostins, B.; Wasielesky, W.; Decamp, O.; Bossier, P.; De Schryver, P. Managing input C/N ratio to reduce the risk of Acute Hepatopancreatic Necrosis Disease (AHPND) outbreaks in biofloc systems-A laboratory study. Aquaculture 2019, 508, 60-65. [CrossRef]

21. Ekasari, J.; Azhar, M.H.; Surawidjaja, E.H.; Nuryati, S.; De Schryver, P.; Bossier, P. Immune response and disease resistance of shrimp fed biofloc grown on different carbon sources. Fish Shellfish Immunol. 2014, 41, 332-339. [CrossRef] [PubMed]

22. Yue, X.; Yu, G.P.; Liu, Z.H.; Lu, Y.Q.; Li, Q.H. Start-up of the completely autotrophic nitrogen removal over nitrite process with a submerged aerated biological filter and the effect of inorganic carbon on nitrogen removal and microbial activity. Bioresour. Technol. 2018, 254, 347-352. [CrossRef] [PubMed]

23. APHA. Standard Methods for the Examination of Water and Wastewater; American Public Health Association (APHA): Washington, DC, USA, 2005.

24. AOAC. Official Methods of Analysis, 18th ed.; AOAC International (Association of Analytical Communities): Gaithersburg, MD, USA, 2005.

25. Lu, S.M.; Liao, M.J.; Zhang, M.; Qi, P.Z.; Xie, C.X.; He, X.G. A rapid DNA extraction method for quantitative real-time PCR amplification from fresh water sediment. J. Food Agric. Environ. 2012, 10, 1252-1255.

26. Herlemann, D.P.; Labrenz, Z.; Jurgens, K.; Bertilsson, S.; Waniek, J.J.; Andersson, A.F. Transitions in bacterial communities along the $2000 \mathrm{~km}$ salinity gradient of the Baltic Sea. ISME J. 2011, 5, 1571-1579. [CrossRef] [PubMed]

27. Wang, Y.; Sheng, H.F.; He, Y.; Wu, J.Y.; Jiang, Y.X.; Tam, N.F.Y.; Zhou, H.W. Comparison of the levels of bacterial diversity in freshwater, intertidal wetland, and marine sediments by using millions of illumina tags. Appl. Environ. Microbiol. 2012, 78, 8264-8271. [CrossRef] [PubMed]

28. Yuan, X.J.; Gao, D.W. Effect of dissolved oxygen on nitrogen removal and process control in aerobic granular sludge reactor. J. Hazard. Mater. 2008, 178, 1041-1045. [CrossRef] [PubMed] 
29. Ferrari, B.; Winsley, T.; Ji, M.; Nielan, B. Insights into the distribution and abundance of the ubiquitous Candidatus Saccharibacteria phylum following tag pyrosequencing. Sci. Rep. 2014, 4, 1-9. [CrossRef]

30. Wasielesky, W.; Atwood, H.; Stokes, A.; Browdy, C.L. Effect of natural production in a zero exchange suspended microbial floc based super-intensive culture system for white shrimp Litopenaeus vannamei. Aquaculture 2006, 258, 396-403. [CrossRef]

31. Yang, S.F.; Li, X.Y. Influences of extracellular polymeric substances (EPS) on the characteristics of activated sludge under non-steady-state conditions. Process Biochem. 2009, 44, 91-96. [CrossRef]

32. Mirzakhani, N.; Ebrahimi, E.; Jalali, S.A.H.; Ekasari, J. Growth performance, intestinal morphology and nonspecific immunity response of Nile tilapia (Oreochromis niloticus) fry cultured in biofloc systems with different carbon sources and input C: N ratios. Aquaculture 2019, 512, 734235. [CrossRef]

33. Xu, G.; Peng, J.; Feng, C.; Fang, F.; Chen, S.; Xu, Y.; Wang, X. Evaluation of simultaneous autotrophic and heterotrophic denitrification processes and bacterial community structure analysis. Appl. Microbiol. Biot. 2015, 99, 6527-6536. [CrossRef] [PubMed]

34. Wang, G.; Xu, X.C.; Gong, Z.; Gao, F.; Yang, F.L.; Zhang, H.M. Study of simultaneous partial nitrification, ANAMMOX and denitrification (SNAD) process in an intermittent aeration membrane bioreactor. Process Biochem. 2016, 51, 632-641. [CrossRef]

35. Wang, J.L.; Gong, B.Z.; Wang, Y.M.; Wen, Y.H.; Zhou, J.; He, Q. The potential multiple mechanisms and microbial communities in simultaneous nitrification and denitrification process treating high carbon and nitrogen concentration saline wastewater. Bioresour. Technol. 2017, 243, 708-715. [CrossRef] [PubMed]

36. Cao, X.; Kunming, F.U.; Qian, D.; Zhu, Z.; Meng, X. Effect of C/N ratio on nitrite accumulation in dentrifying process with methanol as carbon source. Ciesc. J. 2010, 61, 2938-2943.

37. McIntosh, P.R. Changing paradigms in shrimp farming: IV. Low protein feeds and feeding strategies. Glob. Aquac. Advocate 2010, 3, 44-50.

38. Anand, P.S.S.; Kohli, M.P.S.; Kumar, S.; Sundaray, J.K.; Roy, S.D.; Venkateshwarlu, G.; Sinha, A.; Pailan, G.H. Effect of dietary supplementation of biofloc on growth performance and digestive enzyme activities in Penaeus monodon. Aquaculture 2014, 418, 108-115. [CrossRef]

39. Chien, N.V.; Thuy, V.N.; Hideaki, M.; Doan, Y. Factors that Affect the Removal of Nitrogen and Phosphorous from Piggery Wastewater Using Microalgae -Bacteria Consortium. J. Sci. Technol. 2018, 55, 198-203. [CrossRef]

40. Meng, L.Q.; Li, W.G.; Zhang, S.M.; Wu, C.D.; Wang, K. Effects of sucrose amendment on ammonia assimilation during sewage sludge composting. Bioresour. Technol. 2016, 210, 160-166. [CrossRef]

41. Lise, M.H.; Gabriele, L.; Wilson, W.J.; Paulo, C.A. Biofilm versus biofloc: Are artificial substrates for biofilm production necessary in the BFT system? Aquac. Inter. 2016, 24, 921-930.

42. Cardona, E.; Gueguen, Y.; Magre, K.; Lorgeoux, B.; Piquemal, D.; Pierrat, F.; Noguier, F.; Saulnier, D. Bacterial community characterization of water and intestine of the shrimp Litopenaeus stylirostris in a biofloc system. BMC Microbiol. 2016, 16, 157. [CrossRef]

43. Yoon, J.; Yasumoto-Hirose, M.; Katsuta, A.; Sekiguchi, H.; Matsuda, S.; Kasai, H.; Yokota, A. Coraliomargarita akajimensis gen. nov., sp. nov., a novel member of the phylum "Verrucomicrobia" isolated from seawater in Japan. Int. J. Syst. Evol. Microbiol. 2007, 57, 959-963. [CrossRef] [PubMed]

44. Solyanikova, I.P.; Golovleva, L.A. Physiological and biochemical properties of actinobacteria as the basis of their high biodegradative activity (Review). Prikl. Biokhim. Mikrobiol. 2015, 51, 132-139.

45. Hanada, A.; Kurogi, T.; Giang, N.M.; Yamada, T.; Kamimoto, Y.; Kiso, Y.; Hiraishi, A. Bacteria of the candidate phylum TM7 are prevalent in acidophilic nitrifying sequencing-batch reactors. Microbes. Environ. 2014, 29, 353-362. [CrossRef] [PubMed]

46. Zhao, Y.; Park, H.-D.; Park, J.-H.; Zhang, F.; Chen, C.; Li, X.; Zhao, D.; Zhao, F. Effect of different salinity adaptation on the performance and microbial community in a sequencing batch reactor. Bioresour. Technol. 2016, 216, 808-816. [CrossRef] [PubMed]

47. Eo, J.; Park, K.C. Long-term effects of imbalanced fertilization on the composition and diversity of soil bacterial community. Agric. Ecosyst. Environ. 2016, 231, 176-182. [CrossRef]

48. Kindaichi, T.; Yamaoka, S.; Uehara, R.; Ozaki, N.; Ohashi, A.; Albertsen, M.; Nielsen, P.H.; Nielsen, J.L. Phylogenetic diversity and ecophysiology of Candidate phylum Saccharibacteria in activated sludge. FEMS Microbiol. Ecol. 2016, 92, fiw078. [CrossRef] 
49. Zhang, X.T.; Zhang, G.R.; Shi, Z.C.; Yuan, Y.J.; Zheng, H.; Lin, L.; Wei, K.J.; Ji, W. Expression analysis of nine Toll-like receptors in yellow catfish (Pelteobagrus fulvidraco) responding to Aeromonas hydrophila challenge. Fish Shellfish Immunol. 2017, 63, 384-393. [CrossRef]

50. Ahmad, H.I.; Vema, A.K.; Rani, A.M.B.; Rathore, G.; Saharan, N.; Gora, A.H. Growth, non-specific immunity and disease resistance of Labeo rohita against Aeromonas hydrophila in biofloc systems using different carbon sources. Aquaculture 2016, 457, 61-67. [CrossRef]

(C) 2019 by the authors. Licensee MDPI, Basel, Switzerland. This article is an open access article distributed under the terms and conditions of the Creative Commons Attribution (CC BY) license (http://creativecommons.org/licenses/by/4.0/). 